\title{
PERMODELAN INDEKS HARGA KONSUMEN INDONESIA DENGAN MENGGUNAKAN MODEL INTERVENSI MULTI INPUT
}

\author{
P.W. Novianti ${ }^{1}$ \\ Suhartono $^{2}$
}

\begin{abstract}
There are some events which are expected effecting CPI's fluctuation, i.e. financial crisis 1997/ 1998, fuel price risings, base year changing's, independence of Timor-Timur (October 1999), and Tsunami disaster in Aceh (December 2004). During re-search period, there were eight fuel price risings and four base year changing's. The objective of this research is to obtain multi input intervention model which can des-cribe magnitude and duration of each event effected to CPI. Most of intervention re-searches that have been done are only contain of an intervention with single input, ei-ther step or pulse function. Multi input intervention was used in Indonesia CPI case because there are some events which are expected effecting CPI. Based on the result, those events were affecting CPI. Additionally, other events, such as led on January 1999, events on April 2002, July 2003, December 2005, and September 2008, were affecting CPI too. In general, those events gave positive effect to CPI, except events on April 2002 and July 2003 which gave negative effects.
\end{abstract}

Keywords: CPI, Multi Input Intervention, and Fuel Price Rising.

JEL Classification: C22, C43, E31, 138

\footnotetext{
1 Department of Applied Mathematics and Computational Science King Abdullah University of Science and Technology, Saudi Arabia putri.novianti@kaust.edu.sa

2 Jurusan Statistik Institut Teknologi Sepuluh Nopember, Indonesia; suhartono@statistika.its.ac.id
} 


\section{PENDAHULUAN}

Indeks Harga Konsumen (Consumer Price Index / CPI) adalah suatu indeks yang menjelaskan fluktuasi harga dari beberapa barang atau jasa setelah tahun dasar (base year). CPI Indonesia dipengaruhi oleh krisis moneter pada 1997/1998 (Rupingi, 2001) dan kenaikan harga BBM (Rosa, 2006). Selain itu, ada peristiwa-peristiwa lain yang diperkirakan berkontribusi terhadap fluktuasi CPI, mis. perubahan tahun dasar (base year), kemerdekaan Timor-Timur (Oktober 1999), dan bencana Tsunami di Aceh (Desember 2004). Pemerintah dan Bank Indonesia memerlukan studi empiris tentang periode dan besarnya dampak peristiwa-peristiwa tersebut terhadap CPI Indonesia untuk membuat kebijakan yang tepat demi menstabilkan fluktuasi CPI, terutama saat peristiwa-peristiwa tersebut kembali terjadi.

Model kuantitatif yang paling umum digunakan untuk perkiraan waktu (time series) adalah Autoregressive Integrated Moving Average (ARIMA). Akan tetapi, model ARIMA tidak sesuai untuk kasus CPI ini, karena ada beberapa peristiwa yang membuat perubahan pola data. Sebagai salah satu alternatif, permodelan intervensi digunakan untuk kasus ini. Permodelan intervensi digunakan oleh Bhattacharya dan Layton (1979) untuk menganalisa efektifitas undangundang tentang sabuk pengaman di jalan bebas hambatan Queensland, Kendall and Ord (1990) untuk mempelajari dampak aksi demonstrasi pilot di Maskapai Penerbangan Inggris, Leonard (2001) saat menganalisa dampak kenaikan harga dan promosi terhadap permintaan produk, Rupingi (2001) untuk mengetahui dampak krisis moneter tahun 1997/1998 terhadap CPI Indonesia, dan Suhartono (2007) yang mempelajari dampak Bom Bali I terhadap pariwisata di Bali.

Sebagian besar dari penelitian tersebut hanya menggunakan sebuah peristiwa intervensi (input tunggal / single input), baik fungsi step atau pulse. Dalam tulisan ini, digunakan permodelan intervensi multi input karena ada banyak faktor yang mempengaruhi CPI Indonesia. Permodelan Intervensi multi input belum digunakan secara luas dan tidak ada prosedur standar seperti metode Box-Jenkins dalam permodelan ARIMA. Karenanya, dalam penelitian ini, kami mengembangkan permodelan intervensi multi input dalam CPI Indonesia. Sebagai hasilnya, akan dihasilkan suatu model yang bisa menjelaskan periode dan besarnya dampak peristiwaperistiwa tersebut.

\section{TEORI}

Model intervensi adalah suatu model yang bisa digunakan untuk mengevaluasi dampak suatu peristiwa intervensi yang disebabkan oleh faktor internal atau eksternal pada seperangkat data deret waktu (time series) (Suhartono, 2007). Secara umum, ada dua jenis intervensi, yakni 
fungsi step dan pulse. Penjelasan lebih rinci dan penerapan analisa intervensi ini bisa dilihat pada Wei (1990), Bowerman dan O'Connell (1993), Hamilton (1994), Brockwell dan Davis (1996), Tsay (2005) dan Suhartono (2007). Model intervensi bisa dituliskan sebagai berikut

$Y_{t}=\frac{\omega_{s}(B) B^{b}}{\delta_{r}(B)} X_{t}+\frac{\theta_{q}(B)}{\phi_{p}(B)(1-B)^{d}} a_{t}$,

dimana $Y_{t}$ adalah variabel respon pada waktu $t$ dan $X_{t}$ adalah variabel intervensi yang menunjukkan ada atau tidaknya dampak suatu intervensi pada waktu $t$. $X_{t}$ bisa berupa fungsi step $S_{t}$ atau fungsi pulse $P_{t}$. Kemudian, $\omega_{s}(B)$ dan $\delta_{r}(B)$ dijabarkan sebagai

$\omega_{s}(B)=\omega_{0}-\omega_{1} B-\omega_{2} B^{2}-\ldots-\omega_{s} B^{s}$,

dan

$\delta_{s}(B)=1-\delta_{1} B-\delta_{2} B^{2}-\ldots-\delta_{r} B^{r}$.

Persamaan (1) menunjukkan bahwa besar dan periode dampak intervensi ditunjukkan oleh $b$, s, dan $r$. Waktu tunda (delay time) ditunjukkan oleh $b$, s memberikan informasi tentang waktu yang diperlukan agar dampak intervensi menjadi stabil, dan $r$ menunjukkan pola dampak intervensi. Dampak model intervensi pada dataset time series $\left(Y_{t}^{*}\right)$ adalah

$Y_{t}^{*}=Y_{t}-\frac{\theta_{q}(B)}{\phi_{p}(B)(1-B)^{d}} a_{t}=\frac{\omega_{s}(B) B^{b}}{\delta_{r}(B)} X_{t}$

\section{II.1. Model Intervensi Input Tunggal Fungsi Step}

Fungsi step adalah suatu jenis intervensi yang terjadi dalam jangka panjang. Sebagai contoh, analisa sistem perpajakan baru di Australia sejak September 2000 (Valadkhani dan Platon, 2004) telah menerapkan intervensi fungsi step. Intervensi fungsi step dituliskan di bawah ini (Wei, 1990)

$X_{t}=S_{t}= \begin{cases}0, & t<T \\ 1, & t \geq T,\end{cases}$

dimana intervensi dimulai pada T. Model intervensi input tunggal fungsi step dengan $b=2, s=1$, and $r=1$ bisa diperoleh dengan mengganti Persamaan (IV.3) menjadi Persamaan (IV.1),

$Y_{t}=\frac{\left(\omega_{0}-\omega_{1} B\right) B^{2}}{1-\delta_{1}} S_{t}+\frac{\theta_{q}(B)}{\phi_{p}(B)(1-B)^{d}} a_{t}$. 
Karenanya, dampak intervensi input tunggal fungsi step adalah

$$
Y_{t}^{*}=\frac{\left(\omega_{0}-\omega_{1} B\right) B^{2}}{1-\delta_{1}} S_{t}
$$

Jika , maka kita memiliki

$$
Y_{t}^{*}=\omega_{0} S_{t-2}+\left(\omega_{0} \delta_{1}-\omega_{1}\right) S_{t-3}+\left(\omega_{0} \delta_{1}^{2}-\omega_{1} \delta_{1}\right) S_{t-4}+\ldots
$$

Dampak intervensi dalam Persamaan (IV.6) juga bisa dituliskan sebagai

$$
Y_{t}^{*}= \begin{cases}0, & t<T+2 \\ \sum_{i=2}^{k} \omega_{0} \delta_{1}^{i-2}-\sum_{j=3}^{k} \omega_{1} \delta_{1}^{j-3}, & t=T+k, k \geq 2 .\end{cases}
$$

Simulasi dari intervensi tersebut, dimana $\omega_{0}=25, \omega_{1}=-10, \delta_{1}=0,5$ dan terjadi pada $\mathrm{t}=42$ digambarkan pada Grafik IV.1.

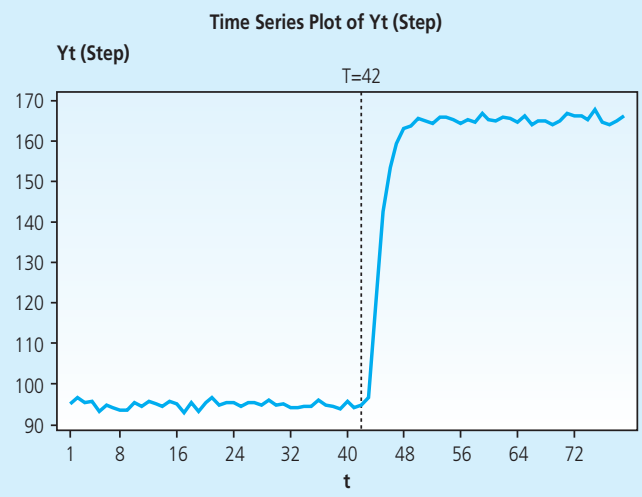

(a)

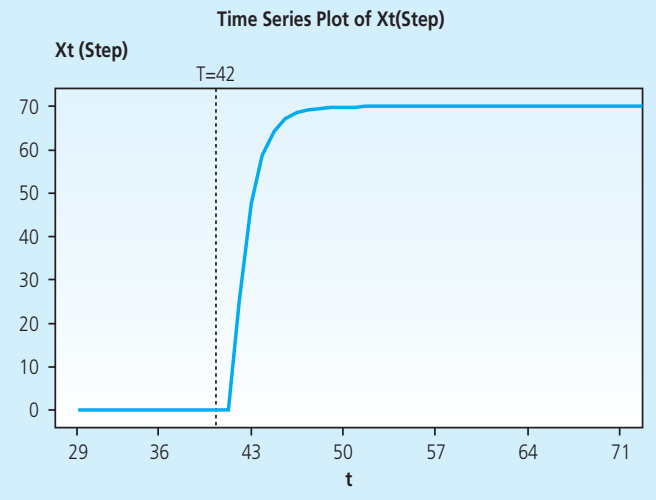

(b)

\section{Grafik IV.1}

Simulasi Model Intervensi

(a) dan Dampak Intervensi (b) dari Input Tunggal Fungsi Step ( $b=2, s=1, r=1$ )

Intervensi tersebut mulai mempengaruhi data pada dua periode berikutnya setelah intervensi terjadi $(b=2)$, dan besarnya adalah 25 . Tiga periode setelah intervensi, eskalasi data adalah 47,5 dan menjadi 64,4 pada periode keempat. Kenaikan ini menjadi dampak permanen dan naik menjadi 70 . 


\section{II.2. Model Intervensi Input Tunggal Fungsi Pulse}

Suatu intervensi yang hanya terjadi pada waktu tertentu $(T)$ disebut dengan intervensi pulse. Contoh dari intervensi ini adalah pemilihan umum dan serangan 11 September di AS yang mempengaruhi tingkat pengangguran di AS (Dholakia, 2003). Fungsi intervensi pulse adalah

$$
X_{t}=P_{t}= \begin{cases}0, & t \neq T \\ 1, & t=T .\end{cases}
$$

Penjelasan dari dampak intervensi input tunggal dengan fungsinpulse bisa dilakukan sama seperti intervensi fungsi step pada Persamaan (IV.4) sampai (IV.7). Simulasi model intervensi input tunggal fungsi step $(b=2, s=1, r=1)$, dimana nilai $\omega_{0}, \omega_{1}$, and $\delta_{1}$, sama dengan simulasi pada Bagian II.2, digambarkan pada Grafik IV.2. Grafik IV.1 dan IV.2 menunjukkan perbedaan antara intervensi step dengan intervensi pulse serta dampaknya. Dampak fungsi step dirasakan dalam jangka panjang, sampai $t>\mathrm{T}$, sementara fungsi pulse memiliki dampak yang tidak permanen, dimana pada $t$ tertentu, dataset time series tidak akan terpengaruh oleh peristiwa intervensi.

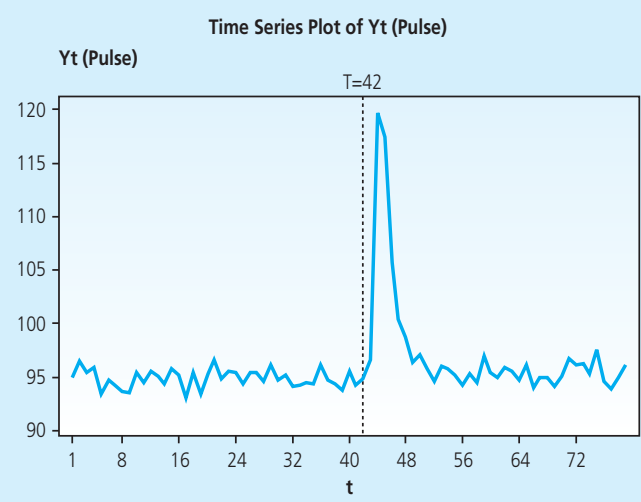

(a)

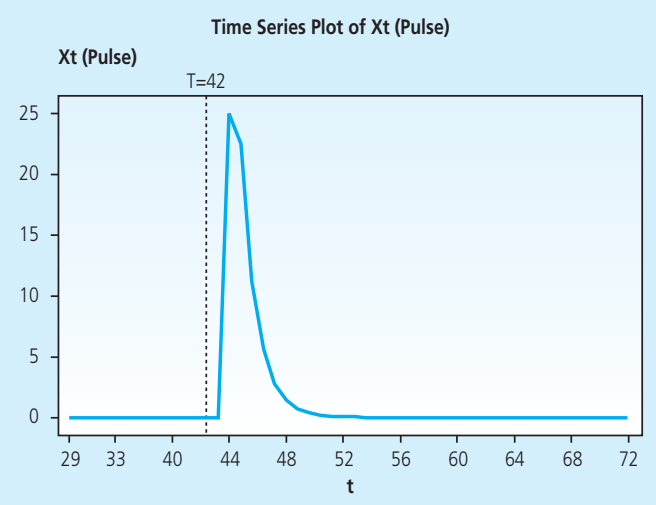

(b)

Grafik IV.2

Simulasi Model Intervensi

(a) dan Dampak Intervensi (b) dari Input Tunggal Fungsi Pulse ( $b=2, s=1, r=1$ ) 


\section{II.3. Model Intervensi Multi Input}

Model intervensi multi input, berdasarkan pada Persamaan (1), adalah (Wei, 1990)

$Y_{t}=\frac{\omega_{s_{1}}(B) B^{b_{1}}}{\delta_{r_{1}}(B)} X_{1 t}+\frac{\omega_{s_{2}}(B) B^{b_{2}}}{\delta_{r_{2}}(B)} X_{2_{t}}+\ldots+\frac{\omega_{s_{k}}(B) B^{b_{k}}}{\delta_{r_{k}}(B)} X_{k_{t}}+\frac{\theta_{q}(B)}{\phi_{p}(B)(1-B)^{d}} a_{t}$

Atau

$Y_{t}=\sum_{i=1}^{k} \frac{\omega_{s_{i}}(B) B^{b_{i}}}{\delta_{r_{i}}(B)} X_{i_{t}}+\frac{\theta_{q}(B)}{\phi_{p}(B)(1-B)^{d}} a_{t}$.

Persamaan (IV.9) menunjukkan bahwa ada peristiwa $k$ pada dataset time series. Sebagai ilustrasi, kita memiliki intervensi multi input dengan dua peristiwa, fungsi pulse $(b=1, s=2, r=0)$ yang diikuti oleh fungsi step $(b=1, s=1, r=1)$,

$Y_{t}=\left[\left(\omega_{0_{1}}-\omega_{1_{1}} B+\omega_{2_{1}}\right) B^{1}\right] P_{t}+\frac{\left(\omega_{0_{2}}-\omega_{1_{2}} B\right) B^{1}}{1-\delta_{1}(B)} S_{t}+\frac{\theta_{q}(B)}{\phi_{p}(B)(1-B)^{d}} a_{t}$.

Dampaknya adalah

$Y_{t}^{*}=\omega_{0_{1}} P_{t-1}-\omega_{1_{1}} P_{t-2}-\omega_{2_{1}} P_{t-3}+\omega_{0_{2}} S_{t-1}+\left(\omega_{0_{2}} \delta_{1}-\omega_{1_{2}}\right) S_{t-2}+\left(\omega_{0_{2}} \delta_{1}-\omega_{1_{2}}\right) \delta_{1} S_{t-3}+\ldots$

juga bisa dituliskan sebagai

$$
Y_{t}^{*}=\left\{\begin{aligned}
0, & t \leq T_{1} \\
\omega_{0_{1}}, & t=T_{1}+1 \\
-\omega_{1_{1}}, & t=T_{1}+2 \\
-\omega_{2_{1}}, & t=T_{1}+3 \\
0, \quad & t=T_{1}+k, T_{1}+k \leq T_{2} \\
\omega_{0_{2}}, & t=T_{2}+1 \\
\left(\omega_{0_{2}}-\omega_{1_{2}}\right)\left(\sum_{i=2}^{k} \delta_{1}^{i-2}\right)+\omega_{0_{2}} \delta_{1}^{k-1}, & t \geq T_{2}+m, m \geq 2 .
\end{aligned}\right.
$$

Visualisasi Persamaan (IV.10) dan dampaknya ditampilkan pada Grafik IV.3, dimana $\omega_{0_{1}}=$ $25, \omega_{1_{1}}=-10, \omega_{2_{1}}=-5, \omega_{0_{2}}=15, \omega_{1_{2}}=-4$ dan $\delta_{1}=0.5$. Intervensi pertama terjadi pada $T_{1}=30$ dan besarnya adalah 25 pada periode di depannya. Intervensi fungsi pulse memiliki pengaruh sampai empat periode setelah $T_{1}$ dimana dampak besarannya adalah 10 dan 5 pada periode ketiga dan keempat. Dampak intervensi pulse adalah nol sampai $T_{2}=54$, saat intervensi kedua dimulai. 
Intervensi step dirasakan satu periode setelah $T_{2}$ dan dampaknya adalah 15. Pada periode kedua sampai kelima, dampak dari intervensi step masing-masing adalah 26,5, 32,25, 36,5, dan 37,3,. Kemudian dampaknya menjadi 38.

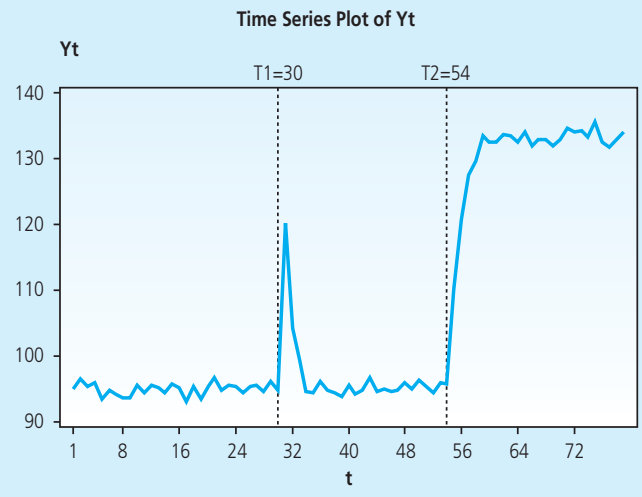

(a)

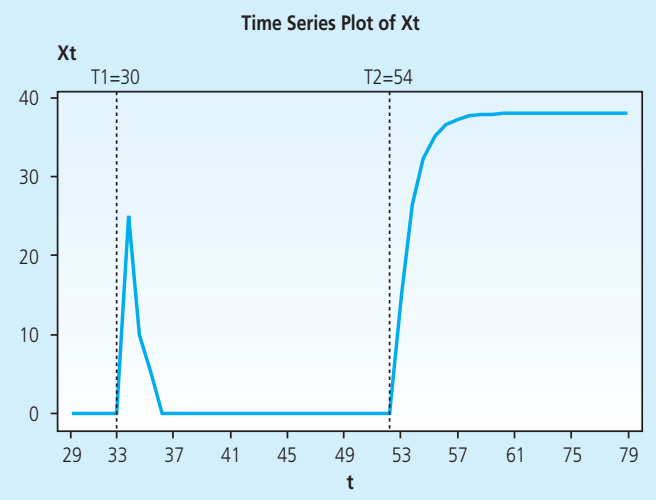

(b)

\section{Grafik IV.3}

Simulasi Model Intervensi

(a) dan Dampak Intervensi (b) Multi Input dimana Fungsi Pulse $(b=1, s=2, r=0)$ terjadi pada $T_{1}=30$ dan Diikuti oleh Fungsi $\operatorname{Step}(b=1, s=1, r=1)$ pada $T_{2}=54$

Sekarang, kami akan menunjukkan model intervensi multi input lain, dimana intervensi fungsi step ( $b=1, s=2, r=0)$ menjadi intervensi pertama dan akan diikuti oleh intervensi fungsi pulse $(b=1, s=1, r=1)$. Modelnya adalah

$Y_{t}=\left[\left(\omega_{0_{1}}-\omega_{1_{1}} B+\omega_{2_{1}}\right) B^{1}\right] S_{t}+\frac{\left(\omega_{0_{2}}-\omega_{1_{2}} B\right) B^{1}}{1-\delta_{1}(B)} P_{t}+\frac{\theta_{q}(B)}{\phi_{p}(B)(1-B)^{d}} a_{t} ，$

dan dampaknya adalah

$Y_{t}^{*}=\omega_{0_{1}} S_{t-1}-\omega_{1_{1}} S_{t-2}-\omega_{2_{1}} S_{t-3}+\omega_{0_{2}} P_{t-1}+\left(\omega_{0_{2}} \delta_{1}-\omega_{1_{2}}\right) P_{t-2}+\left(\omega_{0_{2}} \delta_{1}-\omega_{1_{2}}\right) \delta_{1} P_{t-3}+\ldots$

Intervensi pertama, intervensi fungsi step, mulai mempengaruhi data pada satu periode setelah peristiwa intervensi terjadi, dan dampaknya adalah $\omega_{0_{1}}$. Dampak ini akan menjadi $\left(\omega_{0_{1}}-\omega_{1_{1}}\right)$ pada periode kedua. Pada periode ketiga sampai $t=T_{2}$, dampaknya adalah $\left(\omega_{0_{1}}-\omega_{1_{1}}-\omega_{2_{1}}\right)$. Satu periode setelah itu, intervensi kedua, yakni intervensi fungsi pulse, memberikan dampak tambahan pada dataset time series, $\omega_{0_{2}}$. Karenanya, dampaknya menjadi $\left(\omega_{0_{1}}-\omega_{1_{1}}-\omega_{2_{1}}+\omega_{0_{2}}\right)$. Periode kedua dan ketiga setelah intervensi kedua, dampaknya adalah $\left(\omega_{0_{1}}-\omega_{1_{1}}-\omega_{2_{1}}+\omega_{0_{2}} \delta_{1}-\omega_{1_{2}}\right)$ 
dan $\left(\omega_{0_{1}}-\omega_{1_{1}}-\omega_{2_{1}}+\omega_{0_{2}} \delta_{1}^{2}-\omega_{1_{2}} \delta_{1}\right)$. Kemudian, dampaknya menurun secara bertahap menjadi nol. Akibatnya, dampaknya kembali lagi menjadi $\left(\omega_{0_{1}}-\omega_{1_{1}}-\omega_{2}\right)$.

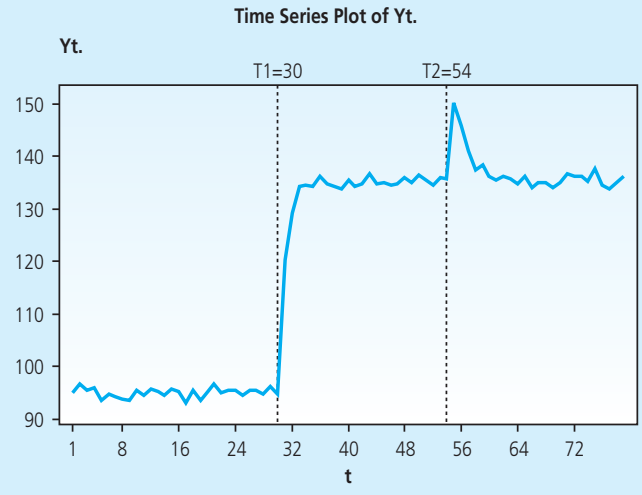

(a)

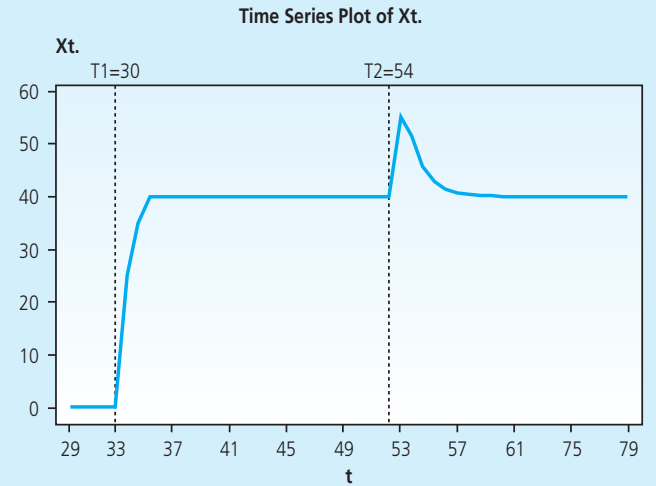

(b)

\section{Grafik IV.4}

Simulasi Model Intervensi (a) dan Dampak Intervensi (b) Multi Input dimana Fungsi Step ( $b=1, s=2, . r=0)$ terjadi pada $T_{1}=30$ dan Diikuti oleh Fungsi Pulse $(b=1, s=1, r=1)$ pada $T_{2}=54$

Grafik IV.4. menunjukkan simulasi intervensi multi input dimana fungsi step adalah peristiwa intervensi pertama dan peristiwa kedua adalah fungsi pulse. Di sini nilai awal untuk simulasi itu adalah $\omega_{0_{1}}=25, \omega_{1_{1}}=-10, \omega_{2_{1}}=-5, \omega_{0_{2}}=15, \omega_{1_{2}}=-4$, dan $\delta_{1}=0.5$. Intervensi pertama, yang terjadi pada $T_{1}=30$, mulai mempengaruhi data pada $t=31$, dan dampaknya adalah 25. Ada kenaikan yang cepat pada dampak intervensi (lihat Grafik IV.4(b)) pada $t=32$ dan $t=35$, namun dampaknya tetap konstan antara $t=35$ dan $t=54$. Intervensi kedua terjadi pada $T_{2}=54$ dan berpengaruh pada dataset pada satu periode ke depan. Dampak tersebut mulai menghasilkan dampak nol sejak periode kelima setelah $T_{2}=54$.

\section{II.4. Estimasi Parameter}

Model intervensi dimana paramater akan diperkirakan dituliskan sebagai

$$
Y_{t}=\frac{\omega_{s}(B)}{\delta_{r}(B)} X_{t-b}+\frac{\theta_{q}(B)}{\phi_{p}(B)(1-B)^{d}} a_{t} .
$$

Tulis ulang Persamaan (IV.12) sebagai 
$\delta_{r}(B) \phi_{p}(B)(1-B)^{d} Y_{t}=\omega_{s}(B) \phi_{p}(1-B)^{d} X_{t-b}+\delta_{r}(B) \theta_{q}(B) a_{t}$,

atau

$c(B) Y_{t}=d(B) X_{t-b}+e(B) a_{t}$

dimana

$$
\begin{aligned}
& c(B)=\delta_{r}(B) \phi_{p}(B)(1-B)^{d}=\left(1-c_{1} B-c_{2} B^{2}-\ldots-c_{p+r} B^{p+r}\right)(1-B)^{d}, \\
& d(B)=\omega_{s}(B) \phi_{p}(1-B)^{d}=\left(d_{0}-d_{1} B-d_{2} B^{2}-\ldots-d_{p+s} B^{p+s}\right)(1-B)^{d}, \\
& e(B)=\delta_{r}(B) \theta_{q}(B)=1-e_{1} B-e_{2} B^{2}-\ldots-e_{r+q} B^{r+q} .
\end{aligned}
$$

Karenanya, kita memiliki

$$
a_{t}=\frac{c(B) Y_{t}-d(B) X_{t-b}}{e(B)} .
$$

Estimasi nonlinear least square untuk memperkirakan parameter tersebut bisa diperoleh dengan meminimalkan

$S(\delta, \omega, \phi, \theta \mid b)=\sum_{t=t_{0}}^{n} a_{t}^{2}$,

dimana $t_{0}=\max (p+r+1, b+p+s+1)$ dan $\alpha_{t}$ adalah residual dalam asumsi white noise dan distribusi Normal. Parameter intervensi multi input bisa diperoleh dengan mengganti Persamaan (IV.12) dengan Persamaan (IV.9) dan mengikuti penjelasan pada Persamaan (IV.13) sampai (IV.15).

\section{METODOLOGI PENELITIAN}

Dataset CPI Indonesia berisi 239 pengamatan, dimulai dari Januari 1989 sampai November 2008. Semua pengamatan (data pelatihan) digunakan untuk membangun model tersebut. Secara umum, ada lima peristiwa intervensi, dimana fungsinya adalah fungsi step, yakni kenaikan harga BBM, perubahan tahun dasar (base year), krisis keuangan tahun 1997/1998, dan Kemerdekaan Timor-Timur. Di sisi lain, bencana Tsunami adalah fungsi pulse. Peristiwa-peristiwa tersebut ditunjukkan pada Tabel IV.1. 


\begin{tabular}{|c|c|c|c|c|}
\hline \multicolumn{5}{|c|}{$\begin{array}{c}\text { Tabel IV.1 } \\
\text { Peristiwa Intervensi pada Dataset CPI Indonesia }\end{array}$} \\
\hline Peristiwa Intervensi & Waktu & Persentase Kenaikan & $\mathbf{t}$ & Nama Variabel \\
\hline \multirow[t]{8}{*}{ Kenaikan harga BBM } & Jul-91 & $22 \%$ & 31 & $X_{31}$ \\
\hline & Jan-93 & $27 \%$ & 49 & $X_{49^{\prime}}$ \\
\hline & Mei-98 & $71,43 \%$ & 113 & $X_{113^{\prime}}$ \\
\hline & Okt -00 & $12 \%$ & 142 & $X_{142^{\prime}}$ \\
\hline & Jan-03 & $21 \%$ & 169 & $X_{169}$ \\
\hline & Mar-05 & $30 \%$ & 195 & $X_{195}$ \\
\hline & Okt-05 & $125 \%$ & 202 & $X_{202^{\prime}}$ \\
\hline & Mei-08 & $30 \%$ & 233 & $X_{233^{\prime}}$ \\
\hline \multirow{3}{*}{$\begin{array}{l}\text { Perubahan Tahun Dasar } \\
\text { (Base Year) }\end{array}$} & Jan-96 & - & 85 & $X_{85}$ \\
\hline & Jan-02 & - & 157 & $X_{157}$ \\
\hline & Jan-07 & - & 217 & $X_{217}$ \\
\hline Krisis Moneter & Jul-97 & - & 103 & $X_{103^{\prime}}$ \\
\hline Kemerdekaan Timor-Timur & Okt -99 & - & 130 & $X_{130^{\prime}}$ \\
\hline Bencana Tsunami & Des-04 & - & 192 & $X_{192^{\prime}}$ \\
\hline
\end{tabular}

Permodelan intervensi multi input pada CPI Indonesia mengikuti algoritma berikut

(1) Membagi dataset menjadi bagian $k+1$,

a. Data 1, yakni data sebelum intervensi pertama, sebanyak $n_{0}$ deret (series) $t=1,2, \ldots$, $T_{1}-1$. Dinotasikan sebagai $Y_{0_{i}}$.

b. Data 2, yakni data dari intervensi pertama sampai sebelum intervensi kedua, sebanyak $n_{1}$ deret, $t=T_{1}, T_{1}+1, T_{1}+2, \ldots, T_{2}-1$. Dinotasikan sebagai $Y_{1_{t}}$.

c. Data $k+1$, yakni data dari intervensi $k^{\text {th }}$ sampai akhir data, sebanyak $n_{\mathrm{k}}$ deret, $t=T_{k}$, $T_{k}+1, T_{k}+2, \ldots, n$. Dinotasikan sebagai $Y_{k_{t}}$.

(2) Permodelan intervensi pertama

a. Langkah 1

- Membangun model ARIMA untuk dataset time series sebelum intervensi pertama terjadi $\left(Y_{0 t}\right)$, jadi kita memiliki

$$
Y_{0_{t}}=\frac{\theta_{q}(B)}{\phi_{p}(B)(1-B)^{d}} a_{t}
$$

- Memprakirakan ke Data $2\left(Y_{1_{t}}\right)$ menggunakan model ARIMA. Pada langkah ini, kita mendapatkan data perkiraan berikut ini

$$
\hat{Y}_{T_{1}-1}(1), \hat{Y}_{T_{1}-1}(2), \ldots, \hat{Y}_{T_{1}-1}\left(n_{1}\right) .
$$


b. Langkah 2

- Hitung nilai respon intervensi pertama atau $Y_{1_{t}}{ }^{*}$. Ini adalah residual data pada $t=T_{1}, T_{1}+1, T_{1}+2, \ldots, T_{2}-1$, berdasarkan pada perkiraan model ARIMA pada langkah pertama. Langkah ini menghasilkan nilai respon dari intervensi pertama,

$Y_{T_{1}}^{*}, Y_{T_{1}+1}^{*}, \ldots, Y_{T_{2}-1}^{*}$

- Identifikasi $b_{1}, s_{1}, r_{1}$ dari intervensi pertama dengan menggunakan plot nilai respon $Y_{T_{1}}^{*}, Y_{T_{1}}^{*}+1, \ldots, Y_{T_{2}}^{*}-1$ dengan menggunakan confidence interval, yakni $\pm 3 \sigma_{a_{0}}$.

- (Root Mean Square Error atau MSE dari model ARIMA sebelumnya). Interval ini didasarkan pada penentuan control chart pada kendali kualitas statistik.

c. Langkah 3

- Estimasi parameter dan uji signifikansi untuk model intervensi pertama

- Pemeriksaan diagnosa, dengan melakukan pemeriksaan asumsi residual, yakni white noise dan Normalitas. Pada langkah ini, kita memiliki model intervensi input pertama

$$
Y_{t}=\frac{\omega_{s_{1}}(B) B^{b_{1}}}{\delta_{r_{1}}(B)} X_{1_{t}}+\frac{\theta_{q}(B)}{\phi_{p}(B)(1-B)^{d}} a_{t} .
$$

(3). Mengembangkan model intervensi- $m^{\text {th }}$ secara iteratif, dimana $m=2,3, \ldots, k$.

a. Langkah 1

- Memperkirakan Data $m+1\left(Y_{m_{t}}\right)$, berdasarkan pada mode intervensi- $m^{\text {th }}$. Pada langkah ini, kita memiliki nilai perkiraan sebagai berikut

$\hat{Y}_{T_{m}-1}(1), \hat{Y}_{T_{m}-1}(2), \ldots, \hat{Y}_{T_{m}-1}\left(n_{m}\right)$.

b. Langkah 2

- Hitung respon intervensi $-m^{\text {th }}\left(Y_{m_{t}}\right)^{*}$, yakni residual pada data $t=T_{m}, T_{m}+1, T_{m}+2, \ldots$, $T_{m+1}-1$, berdasarkan pada perkiraan model intervensi- $(m-1)^{\text {th }}$. Pada langkah ini, kita memiliki nilai respon dari intervensi $-m^{\text {th }}$,

$Y_{T_{m}}^{*}, Y_{T_{m}+1}^{*}, \ldots, Y_{T_{m+1}-1}^{*}$

- Identifikasi $b_{m^{\prime}} s_{m^{\prime}}, r_{m}$ dari model intervensi $m^{\text {th }}$, plot respon $Y_{T_{m}}^{*}+1, \ldots, Y_{T_{m+1}^{*}}^{*}-1$, dimana confidence interval adalah $\pm 3 \sigma_{a_{m-1}}$. 
c. Langkah 3

- Estimasi parameter dan uji signifikansi untuk model intervensi $m^{\text {th }}$

- Pemeriksaan diagnosa, dengan melakukan uji asumsi residual, yakni white noise dan uji Normalitas. Pada langkah ini, kita memiliki

$$
\sum_{j=1}^{m} \frac{\omega_{s_{j}}(B) B^{b_{j}}}{\delta_{r_{j}}(B)} X_{j_{t}}+\frac{\theta_{q}(B)}{\phi_{p}(B)(1-B)^{d}} a_{t} .
$$

Langkah ini dilakukan secara iteratif sampai intervensi terakhir, yakni intervensi $-m^{\text {th }}$. Karenanya, kita mendapatkan model intervensi multi input

$$
Y_{t}=\sum_{j=1}^{m} \frac{\omega_{s_{j}}(B) B^{b_{j}}}{\delta_{r_{j}}(B)} X_{j_{t}}+\frac{\theta_{q}(B)}{\phi_{p}(B)(1-B)^{d}} a_{t} .
$$

\section{HASIL EMPIRIS}

CPI Indonesia cenderung meningkat tiap bulannya. Ada beberapa kenaikan dramatis dalam CPI Indonesia yang bisa dilihat pada Grafik IV.5.

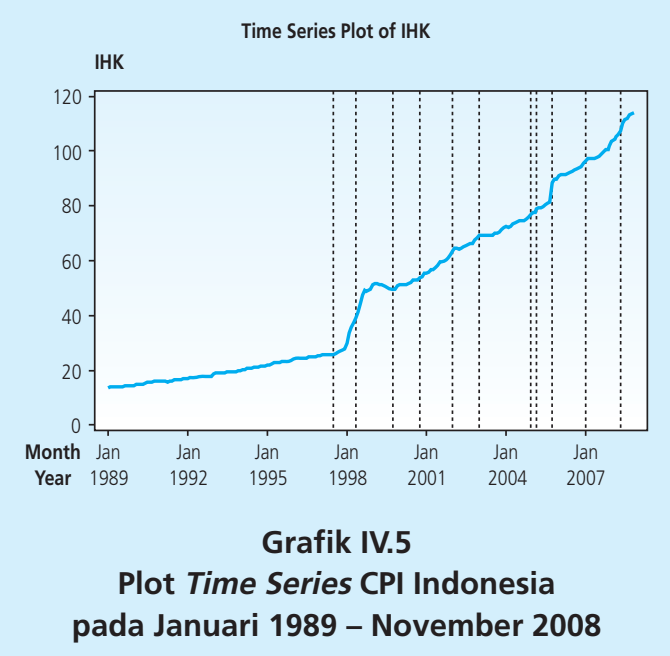

Kenaikan CPI Indonesia yang paling signifikan terjada pada saat krisis moneter pada 1997/1998 dan kenaikan harga BBM pada Oktober 2005. Berdasarkan pada Info Bank Publishing (2007), ada banyak pemutusan hubungan kerja, penutupan beberapa bank, dan kondisi politik yang tidak stabil. Karenanya, paritas daya beli konsumen (consumer power parity) menurun secara signifikan dan mempengaruhi CPI Indonesia. 
Penentuan model intervensi multi input pada CPI Indonesia mengikuti algoritma pada Bagian III. Pada bagian berikutnya, kami akan memberi penjelasan singkat tentang bagaimana cara membangun model serta dampak tiap peristiwa intervensi. Akan tetapi, kami hanya memaparkan sebuah peristiwa dari tiap kategori peristiwa intervensi. Misalnya, kami menggunakan kenaikan harga BBM pada Mei 2008 untuk mewakili peristiwa kenaikan harga BBM.

\section{IV.1. Permodelan Pra Intervensi}

Prosedur Box-Jenkins digunakan untuk menentukan model pra intervensi, yakni ARIMA. Rincian tentang prosedue Box-Jenkins bisa dilihat dalam Bowerman dan O'Connell (1993). Menurut Tabel IV.1, peristiwa intervensi pertama adalah kenaikan harga BBM pada Juli 1991. Akan tetapi, data yang harus digunakan untuk menentukan model ARIMA tidak memadai. Untuk mendapatkan model ARIMA, peneliti harus memiliki setidaknya lima puluh pengamatan (Wei, 1990). Karenanya, kami mengasumsikan krisis moneter sebagai peristiwa intervensi pertama dalam dataset CPI Indonesia.

Setelah mengidentifikasi data dengan menggunakan transformasi Box Cox, kami berkesimpulan bahwa data tidak perlu ditransformasi. Akan tetapi, uji Augmented Dickey Fuller menunjukkan bahwa dataset memiliki rata-rata (mean) yang tidak konstan. Karenanya, digunakan pembedaan untuk mendapatkan data statis (Wei, 1990). Berdasarkan pada plot ACF dan PACF, ada beberapa kemungkinan urutan ARIMA. Akan tetapi, ARIMA $(0,1,1)(0,0,1)^{12}$ adalah model terbaik, karena memiliki MSE terkecil, semua parameter memiliki signifikansi statistik, dan residualnya white noise. Sayangnya, model ini tidak memenuhi distribusi Normal. Ini mungkin disebabkan oleh outlier pada dataset. Setelah memasukkan outlier dalam model ARIMA dan memperkirakan kembali parameter, kami mendapatkan model yang memenuhi asumsi residual, baik white noise dan Normalitas, yakni

$$
Y_{t}=0.11+0.35 X_{31_{t}}+0.27 X_{49_{t}}+0.2 X_{87_{t}}+Y_{t-1}+a_{t}+0.3 a_{t-1}+0.48 a_{t-12}+0.15 a_{t-13} .
$$

MSE Model (IV.18) adalah 0,0087. Model ini menunjukkan bahwa data sebelum intervensi dipengaruhi oleh kenaikan harga BBM pada Juli 1991 dan Januari 1993, dan juga peristiwa pada Maret 1996. 


\section{IV.2. Permodelan Intervensi atas CPI Indonesia}

Peristiwa intervensi pertama yang mempengaruhi CPI Indonesia adalah krisis moneter pada tahun 1997/1998. Ini adalah intervensi fungsinstep. Berdasarkan pada Grafik IV.6, pola data perkiraan model ARIMA (garis hijau) berbeda dengan pola data sebelum intervensi (garis merah). Ini menunjukkan bahwa intervensi terjadi dan memiliki dampak signifikan. Langkah pertama dalam permodelan intervensi adalah mengidentifikasi nilai $b, s$, dan $r$. Identifikasi ini dilakukan dengan mengevaluasi model pra intervensi ke dalam bar chart residual (Grafik IV.6(b)).

Berdasarkan pada Grafik IV.6(b), kita mendapatkan $b=2, s=[1,4,5,6,7]$, dan $r=0$. Hasil estimasi parameter dan uji signifikansi menunjukkan bahwa semua parameter adalah signifikan, jadi model intervensi dituliskan sebagai

$$
\begin{aligned}
Y_{t}= & 0.11+0.3 X_{31_{t}}+0.3 X_{49_{t}}-0.2 X_{87_{t}}+0.2 X_{103_{t-2}}+0.3 X_{103_{t-3}}+0.2 X_{103_{t-6}}+3.7 X_{103_{t-7}}+ \\
& 1.8 X_{103_{t-8}}+1.5 X_{103_{t-9}}+Y_{t-1}+a_{t}+0.59 a_{t-1}+0.44 a_{t-12}+0.26 a_{t-13}
\end{aligned}
$$

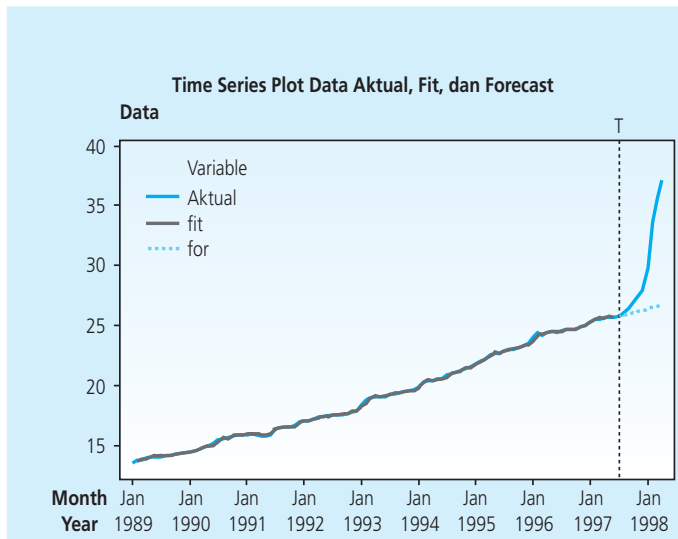

(a)

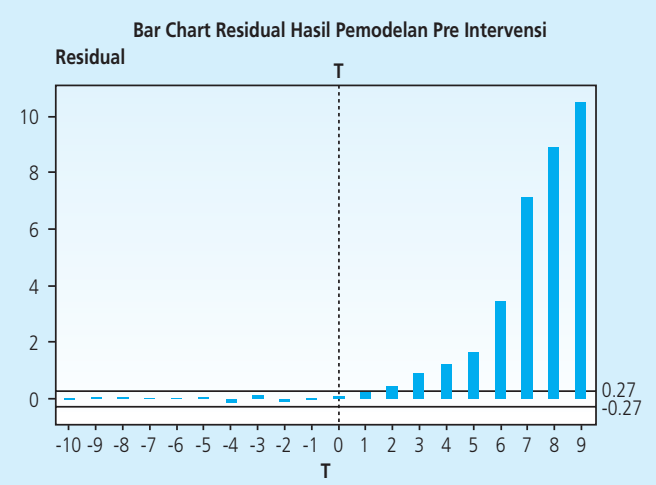

(b)

\section{Grafik IV.6}

(a) Plot Time Series (b) Bar Chart Residual dari Model Pra Intervensi

Model (IV.19) menunjukkan bahwa krisis moneter memberikan eskalasi positif. Dua bulan setelah terjadi intervensi, besarnya intervensi adalah 0,2. Eskalasi ini menjadi 7,7 pada bulan kesembilan setelah intervensi.nRincian dampak krisis moneter ditampilkan pada Tabel IV.2. 


\begin{tabular}{|c|c|c|}
\hline \multicolumn{3}{|c|}{$\begin{array}{c}\text { Tabel IV.2 } \\
\text { Dampak Krisis Moneter bagi CPI Indonesia }\end{array}$} \\
\hline Waktu (t) & Bulan & Besarnya Dampak \\
\hline $\begin{array}{l}T+2 \\
T+3-T+5 \\
T+6 \\
T+7 \\
T+8 \\
T+9\end{array}$ & $\begin{array}{l}\text { September } 1997 \\
\text { Oktober - Desember } 1997 \\
\text { Januari } 1998 \\
\text { Februari } 1998 \\
\text { Maret } 1998 \\
\text { April } 1998\end{array}$ & $\begin{array}{l}0,2 \\
0,2+0,3=0,5 \\
0,2+0,3+0,2=0,7 \\
0,2+0,3+0,2+3,7=4,4 \\
0,2+0,3+0,2+3,7+1,8=6,2 \\
0,2+0,3+0,2+3,7+1,8+1,5=7,7\end{array}$ \\
\hline
\end{tabular}

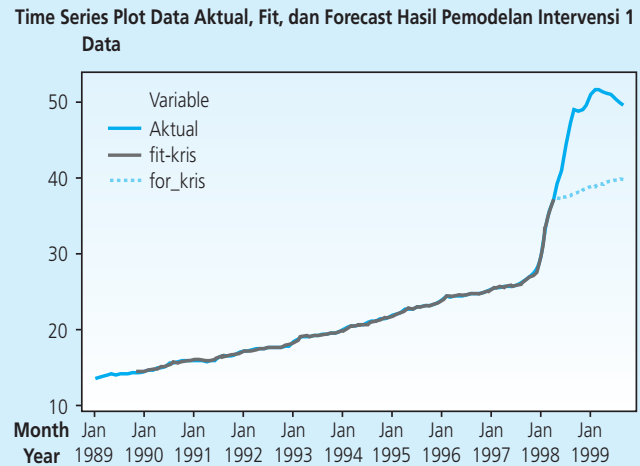

(a)

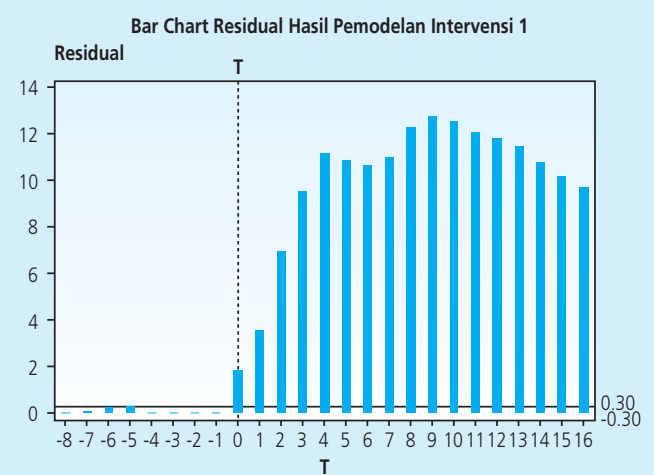

(b)

Grafik IV.7

(a) Plot Time Series (b) Bar Chart Residual dari Model Intervensi karena Krisis Moneter

Intervensi kedua adalah kenaikan harga BBM pada bulan Mei 1998 (25-71,43\%). Intervensi ini memberi tambahan eskalasi bagi CPI Indonesia. Berdasarkan pada hasil pada Grafik IV.7(b), kita memperoleh $b=0, s=4$, dan $r=0$. Model intervensi adalah

$$
\begin{aligned}
Y_{t}= & 0.1+0.4 X_{31_{t}}+0.3 X_{49_{t}}-0.1 X_{87_{t}}+0.3 X_{103_{t-3}}+0.3 X_{103_{t-3}}+1.2 X_{103_{t-6}}+3.4 X_{103_{t-7}}+ \\
& 1.8 X_{103_{t-8}}+1.7 X_{103_{t-9}}+1.9 X_{113_{t}}+1.9 X_{113_{t-1}}+3.8 X_{113_{t-2}}+2.9 X_{113_{t-3}}+1.9 X_{113_{t-4}}+ \\
& Y_{t-1}+a_{t}+0.8 a_{t-1}+0.95 a_{t-12}+0.7 a_{t-13},
\end{aligned}
$$

dan dampaknya dipaparkan pada Tabel IV.3. Hasil ini menunjukkan bahwa kebijakan pemerintah berdampak langsung terhadap CPI. Pada bulan pertama (bulan yang sama saat peristiwa terjadi), CPI naik hampir 2 poin dan naik 3,8 poin pada bulan berikutnya. Selain itu, CPI pada September 1998 12,4 poin lebih tinggi daripada pada bulan sebelum peraturan ini diterapkan. Ini menunjukkan bahwa kenaikan harga BBM yang terjadi pada era krisis memiliki dampak cukup besar pada CPI. 


\begin{tabular}{|c|c|c|}
\hline Waktu (t) & Bulan & Besarnya Dampak \\
\hline $\mathrm{T}$ & Mei 1998 & 1,9 \\
\hline$T+1$ & Juni 1998 & $1,9+1,9=3,8$ \\
\hline$T+2$ & Juli 1998 & $1,9+1,9+3,8=7,6$ \\
\hline$T+3$ & Agustus 1998 & $1,9+1,9+3,8+2,9=10,5$ \\
\hline $\mathrm{T}+4$ & September 1998 & $1,9+1,9+3,8+2,9+1,9=12,4$ \\
\hline
\end{tabular}

Permodelan intervensi multi input dilanjutkan dengan mendeteksi urutan untuk intervensi berikutnya, yakni kemerdekaan Timor-Timur. Secara teoritis, Timor-Timur tidak menjadi bagian dari Indonesia sejak 2002, namun BPS tidak memasukkan Dili (bekas ibukota Timor-Timur) dalam penghitungan CPI sejak Oktober 1999. Karenanya, kami berasumsi bahwa kemerdekaan Timor-Timur terjadi pada Oktober 1999. Sebagaimana intervensi sebelumnya, deteksi urutan dilakukan dengan mengevaluasi model intervensi sebelumnya pada bar chart residual.

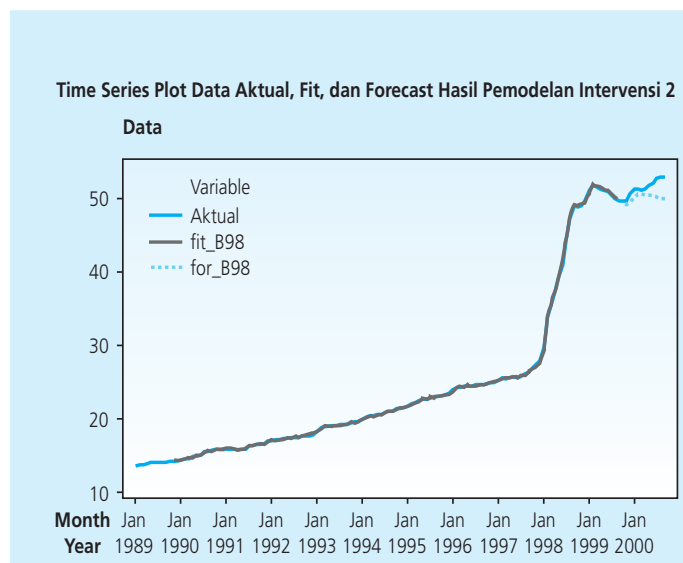

(a)

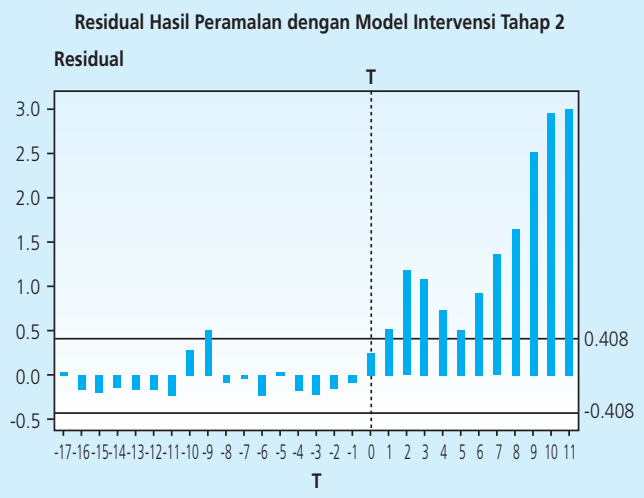

(b)

\section{Grafik IV.8}

(a) Plot Time Series (b) Bar Chart Residual dari Model Intervensi karena Kenaikan Harga BBM pada Mei 1999

Karenanya, kita mendapatkan model intervensi multi input baru sebagai berikut

$$
\begin{aligned}
Y_{t}= & 0.1+0.4 X_{31_{t}}+0.3 X_{49_{t}}-0.1 X_{87_{t}}+0.3 X_{103_{t-2}}+0.3 X_{103_{t-3}}+1.2 X_{103_{t-6}}+3.3 X_{103_{t-7}}+ \\
& 1.8 X_{103_{t-8}}+1.8 X_{103_{t-9}}+2.1 X_{113_{t}}+2 X_{113_{t-1}}+3.8 X_{113_{t-2}}+2.9 X_{113_{t-3}}+1.9 X_{113_{t-4}}+ \\
& 0.6 X_{130_{t-2}}+0.7 X_{130_{t-9}}+0.4 X_{130_{t-9}}+0.4 X_{130_{t-10}}+Y_{t-1}+a_{t}+0.8 a_{t-1}+0.9 a_{t-12}+0.8 a_{t-13}
\end{aligned}
$$


Berdasarkan pada model tersebut, dampaknya dituliskan pada Tabel 4. Kemerdekaan Timor-Timur mulai mempengaruhi dataset CPI dua bulan setelah peristiwa. Eskalasinya tetap stabil pada Desember 1999 - Juni 2000, namun ada sedikit kenaikan dalam CPI Indonesia pada Juli dan Agustus 2000.

\begin{tabular}{|c|c|c|}
\hline \multicolumn{3}{|c|}{$\begin{array}{c}\text { Tabel IV.4 } \\
\text { Dampak Kemerdekaan Timor-Timur terhadap CPI Indonesia }\end{array}$} \\
\hline Waktu (t) & Bulan & Besarnya Dampak \\
\hline$T+2-T+8$ & Desember 1999 - Juni 2000 & 0,6 \\
\hline$T+9$ & Juli 2000 & $0,6+0,7=1,3$ \\
\hline$T+10$ & Agustus 2000 & $0,6+0,7+0,4=1,7$ \\
\hline$T+11$ & September 2000 & $0,6+0,7+0,4=1,7$ \\
\hline
\end{tabular}

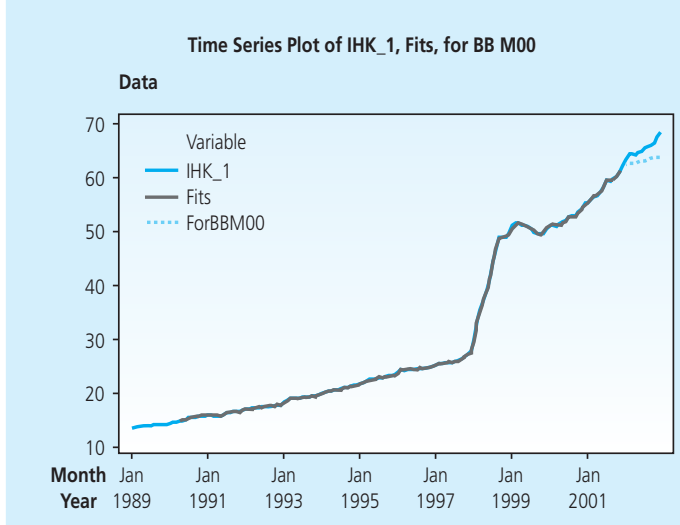

(a)

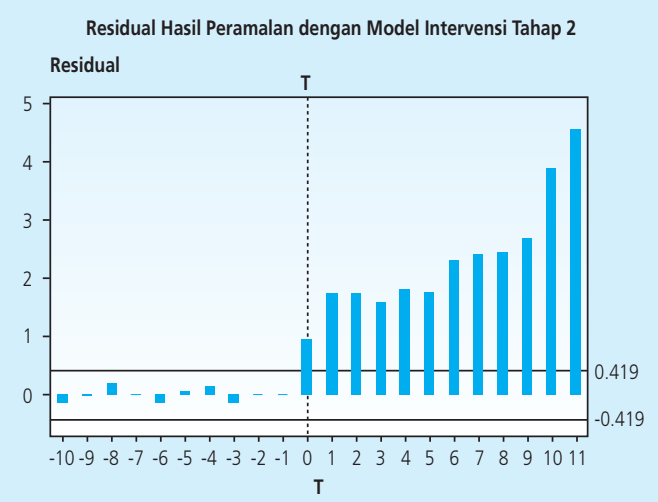

(b)

\section{Grafik IV.9}

\section{(a) Plot Time Series (b) Bar Chart Residual dari Model Intervensi karena Kenaikan Harga BBM pada Oktober 1999}

Berdasarkan pada hasil pada Tabel IV.1, intervensi berikutnya adalah kenaikan harga BBM pada Oktober 2000. Dengan menggunakan langkah yang sama seperti pada intervensi sebelumnya, kami mendapatkan model intervensi baru. Kemudian, kami menggunakan model tersebut untuk mengidentifikasi urutan peristiwa intervensi berikutnya, yakni perubahan tahun dasar (base year) pada tahun 2002. Pada tiap perubahan tahun dasar (base year), BPS selalu menambah jumlah komoditas dan kota. Untuk mengetahui dampak dari penambahan ini, kami menganggap ini sebagai suatu peristiwa intervensi. Grafik IV.9 menunjukkan bahwa peristiwa intervensi mempengaruhi dataset CPI. Estimasi dan uji signifikansi untuk parameter menghasilkan model intervensi sebagai berikut 


$$
\begin{aligned}
Y_{t}= & 0.1+0.3 X_{31_{t}}+0.3 X_{49_{t}}+0.3 X_{103_{t-2}}+0.3 X_{103_{t-3}}+1.2 X_{103_{t-6}}+3.3 X_{103_{t-7}}+1.7 X_{103_{t-8}}+ \\
& 1.8 X_{103_{t-9}}+2.1 X_{113_{t}}+1.9 X_{113_{t-1}}+3.8 X_{113_{t-2}}+2.8 X_{113_{t-3}}+1.8 X_{113_{t-4}}+0.6 X_{130_{t-2}}+ \\
& 0.9 X_{130_{t-9}}+0.7 X_{130_{t-10}}+0.7 X_{142_{t-2}}+0.5 X_{142_{t-4}}+0.7 X_{142_{t-5}}+0.5 X_{142_{t-8}}+1.03 X_{142_{t-9}}+ \\
& 0.7 X_{142_{t-13}}+0.7 X_{142_{t-14}}+0.9 X_{157_{t}}+0.6 X_{157_{t-1}}+1.1 X_{157_{t-10}}+0.7 X_{157_{t-11}}+Y_{t-1}+a_{t}+ \\
& 0.7 a_{t-1}+0.9 a_{t-12}+0.7 a_{t-13}
\end{aligned}
$$

Pemerintah menaikkan harga BBM pada Januari 2003. Persentase kenaikannya adalah 3 sampai 28 persen. Yang mengejutkan, kebijakan pemerintah ini tidak mempengaruhi CPI. Hal ini bisa terlihat pada Gambar IV.10, dimana tidak ada residual yang keluar dari confidence interval. Akan tetapi, residual pada $t=175$ dan $t \geq 180$ ada di luar batas. Ini menunjukkan bahwa ada dampak intervensi lain dalam dataset CPI. Setelah memasukkan pengamatan tersebut dan memperkirakan kembali koefisien parameter, model dituliskan kembali sebagai

$$
\begin{aligned}
Y_{t}= & 0.2+0.3 X_{31_{t}}+0.3 X_{49_{t}}+0.3 X_{103_{t-2}}+0.3 X_{103_{t-3}}+1.2 X_{103_{t-6}}+3.3 X_{103_{t-7}}+1.7 X_{103_{t-8}}+ \\
& 1.8 X_{103_{t-9}}+2.1 X_{113_{t}}+2 X_{113_{t-1}}+3.8 X_{113_{t-2}}+2.8 X_{113_{t-3}}+1.8 X_{113_{t-4}}+0.6 X_{130_{t-2}}+ \\
& 0.9 X_{130_{t-9}}+0.7 X_{130_{t-10}}+0.7 X_{142_{t-2}}+0.4 X_{142_{t-4}}+0.5 X_{142_{t-5}}+0.5 X_{142_{t-8}}+1.03 X_{142_{t-9}}+ \\
& 0.6 X_{142_{t-13}}+0.4 X_{142_{t-14}}+0.8 X_{157_{t}}+0.5 X_{157_{t-1}}+0.7 X_{157_{t-10}}-0.4 X_{175_{t}}+Y_{t-1}+a_{t}+ \\
& 0.7 a_{t-1}+0.9 a_{t-12}+0.7 a_{t-13}
\end{aligned}
$$

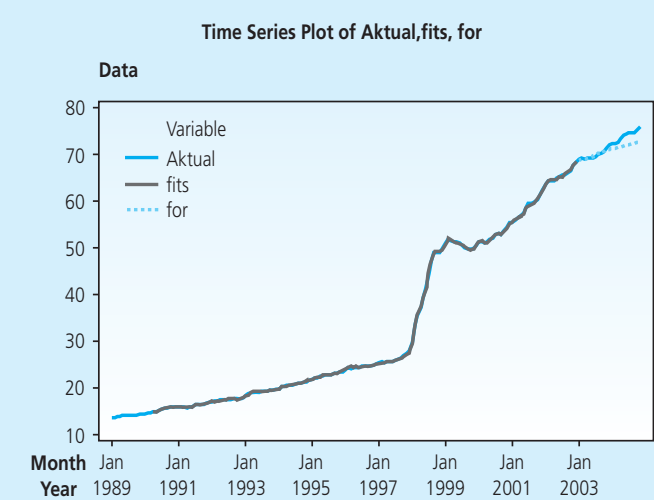

(a)

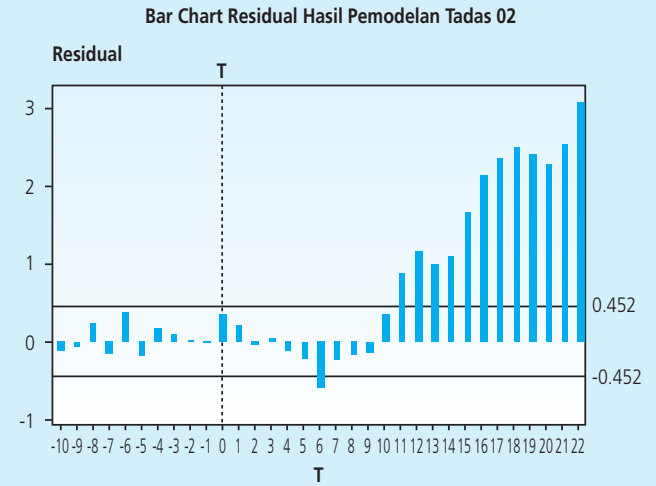

(b)

\section{Grafik IV.10}

(a) Plot Time Series (b) Bar Chart Residual dari Model Intervensi karena perubahan tahun dasar (base year) pada tahun 2002 
Model (IV.20) digunakan untuk memperoleh urutan bencana Tsunami, yang merupakan peristiwa intervensi berikutnya. Model intervensi baru setelah memasukkan peristiwa intervensi ini adalah

$$
\begin{aligned}
Y_{t}= & 0.2+0.3 X_{31_{t}}+0.3 X_{49_{t}}+0.2 X_{103_{t-2}}+0.3 X_{103_{t-3}}+1.2 X_{103_{t-6}}+3.3 X_{103_{t-7}}+1.6 X_{103_{t-8}}+ \\
& 1.8 X_{103_{t-9}}+2.2 X_{113_{t}}+2 X_{113_{t-1}}+3.8 X_{113_{t-2}}+2.8 X_{113_{t-3}}+1.8 X_{113_{t-4}}+0.6 X_{130_{t-2}}+ \\
& 0.9 X_{130_{t-9}}+0.8 X_{130_{t-10}}+0.5 X_{142_{t-2}}+0.4 X_{142_{t-4}}+0.5 X_{142_{t-5}}+0.5 X_{142_{t-8}}+0.9 X_{142_{t-9}}+ \\
& 0.5 X_{142_{t-13}}+0.6 X_{157_{t}}+0.5 X_{157_{t-1}}+0.7 X_{157_{t-10}}-0.4 X_{175_{t}}+0.5 X_{192_{t-1}}+Y_{t-1}+a_{t}+ \\
& 0.7 a_{t-1}+0.9 a_{t-12}+0.7 a_{t-13}
\end{aligned}
$$

Model tersebut memberikan informasi bahwa bencana Tsunami mempengaruhi CPI hanya pada bulan pertama setelah peristiwa. Kenaikan CPI adalah 0,5 pada Januari 2005.

Dengan menggunakan langkah yang sama, permodelan intervensi dengan semua peristiwa intervensi pada Tabel (IV.1) menghasilkan intervensi multi input sebagai berikut

$$
\begin{aligned}
Y_{t}= & 0.1+0.3 X_{31_{t}}+0.3 X_{49_{t}}+1.2 X_{103_{t-6}}+3.4 X_{103_{t-7}}+1.8 X_{103_{t-8}}+1.7 X_{103_{t-9}}+ \\
& 1.9 X_{113_{t}}+1.8 X_{113_{t-1}}+3.5 X_{113_{t-2}}+2.8 X_{113_{t-3}}+1.9 X_{113_{t-4}}+0.4 X_{121_{t}}+ \\
& 0.4 X_{130_{t-2}}+0.6 X_{130_{t-9}}+0.5 X_{130_{t-10}}+0.6 X_{142_{t-2}}+0.4 X_{142_{t-8}}+1.1 X_{142_{t-9}}+ \\
& 0.5 X_{142_{t-13}}+0.7 X_{157_{t}}+0.8 X_{157_{t-1}}+0.7 X_{157_{t-10}}-0.3 X_{160_{t}}-0.3 X_{175_{t}}+ \\
& 0.4 X_{192_{t-1}}+1.2 X_{195_{t}}+6.3 X_{202_{t}}+0.7 X_{202_{t-1}}+0.6 X_{202_{t-14}}+0.4 X_{204_{t}}+ \\
& 0.7 X_{224_{t-4}}+1.1 X_{224_{t-5}}+0.6 X_{224_{t-7}}+0.5 X_{224_{t-8}}+1.3 X_{233_{t}}+2.4 X_{233_{t-1}}+ \\
& 0.9 X_{233_{t-2}}+0.5 X_{273_{t}}+Y_{t-1}+\frac{\left(1+0.7 B+0.1 B^{7}\right)}{1-0.6 B^{12}}
\end{aligned}
$$

Model intervensi multi input (IV.21) memiliki nilai kurtosis yang tinggi. Ini bisa disebabkan karena banyak residual yang bernilai nol. RMSE dari model intervensi multi input ini adalah 0,184 .

Selain peristiwa-peristiwa yang tercantum pada Tabel IV.1, Persamaan (IV.21) menunjukkan bahwa Idul Fitri pada Januari $1999\left(X_{121}\right)$, peristiwa pada Desember 2005 dan September 2008 $\left(X_{237}\right)$ berdampak positif bagi CPI Indonesia. Sementara, peristiwa pada April $2002\left(X_{160}\right)$ dan Juli $2003\left(X_{175}\right)$ berdampak negatif pada CPI Indonesia. Tabel IV.2 memaparkan informasi rinci tentang dampak tiap peristiwa. Kenaikan harga BBM cenderung memberikan dampak langsung 
dan positif terhadap CPI. Selama periode penelitian, hanya ada satu kali kenaikan harga BBM yang tidak mempengaruhi CPI yang terjadi pada Januari 2003. Sebaliknya, persentase tertinggi kenaikan harga BBM terjadi pada Oktober 2005 (125 persen), akibatnya, CPI naik lebih dari 6 poin pada bulan tersebut.

Pada era Order Baru, kenaikan harga BBM tidak memiliki dampak yang besar. Akan tetapi, hal ini cukup berdampak pada era Reformasi. Misalnya, hanya ada sedikit kenaikan CPI karena kenaikan harga BBM pada Januari 1993 (27 persen), namun peraturan ini menyebabkan kenaikan CPI yang tinggi saat persentase eskalasinya hanya 30 persen (Maret 2005). Ini menunjukkan bahwa CPI lebih sensitif terhadap kenaikan harga BBM pada era Reformasi dibandingkan pada era Order Baru.

\begin{tabular}{|c|c|c|c|c|c|}
\hline \multicolumn{6}{|c|}{$\begin{array}{c}\text { Tabel IV.5 } \\
\text { Dampak Intervensi pada CPI Indonesia }\end{array}$} \\
\hline Intervensi & Waktu & $\begin{array}{c}\text { Persentase } \\
\text { Kenaikan }\end{array}$ & $\begin{array}{c}\text { Dirasakannya } \\
\text { Dampak Pertama }\end{array}$ & Jenis Dampak & $\begin{array}{c}\text { Damapak } \\
\text { Periode Pertama }\end{array}$ \\
\hline Kenaikan harga & Jul-91 & $22 \%$ & Langsung & Positif \& Permanen & 0,3 \\
\hline \multirow[t]{7}{*}{ BBM } & Jan-93 & $27 \%$ & Langsung & Positif \& Permanen & 0,3 \\
\hline & Mei-98 & $71 \%$ & Langsung & Positif \& Permanen & 1,9 \\
\hline & Okt-00 & $12 \%$ & Setelan 2 bulan & Positif \& Permanen & 0,6 \\
\hline & Jan-03 & $21 \%$ & - & - & - \\
\hline & Mar-05 & $30 \%$ & Langsung & Positif \& Permanen & 1,2 \\
\hline & Okt-05 & $125 \%$ & Langsung & Positif \& Permanen & 6,3 \\
\hline & Mei-08 & $30 \%$ & Langsung & Positif \& Permanen & 1,3 \\
\hline Perubahan & Jan-96 & - & - & - & - \\
\hline Tahun Dasar & Jan-02 & - & Directly & Positif \& Permanen & 0,7 \\
\hline (Base Year) & Jan-07 & - & - & - & - \\
\hline Krisis Moneter & Jul-97 & - & Setelan 6 bulan & Positif \& Permanen & 1,2 \\
\hline $\begin{array}{l}\text { Kemerdekaan } \\
\text { Timor-Timur }\end{array}$ & Okt-99 & - & Setelan 2 bulan & Positif \& Permanen & 0,6 \\
\hline Bencana Tsunami & Des-04 & - & Setelan 1 bulan & Positif \& Sementara & 0,4 \\
\hline Idul Fitri & Jan-99 & - & Langsung & Positif \& Sementara & 0,4 \\
\hline Peristiwa & Apr-02 & - & Langsung & Negatif \& Sementara & $-0,3$ \\
\hline \multirow[t]{3}{*}{ Tak Diketahui } & Jul-03 & - & Langsung & Negatif \& Permanen & $-0,3$ \\
\hline & Des-05 & - & Langsung & Positif \& Sementara & 0,4 \\
\hline & Sept-08 & - & Langsung & Positif \& Permanen & 0,5 \\
\hline
\end{tabular}

Krisis moneter pada tahun 1997/1998 berdampak positif dan permanen terhadap CPI. Meskipun dampaknya baru dirasakan enam bulan setelah krisis dimulai, CPI secara bertahap naik pada bulan tersebut, yakni 1,2. Peristiwa lain, kemerdekaan Timor-Timur juga berdampak positif dan permanen. 


\section{KESIMPULAN}

Secara umum, kami berkesimpulan bahwa model intervensi multi input yang telah diperoleh bisa menjelaskan dengan tepat tentang dampak dari peristiwa-peristiwa yang mempengaruhi CPI Indonesia selama Januari 1989 - November 2008. Berdasarkan pada model tersebut, ada beberapa peristiwa yang secara signifikan mempengaruhi CPI, yakni kenaikan harga BBM, krisis moneter, perubahan tahun dasar (base year) pada Januari 2002, kemerdekaan Timor-Timur, bencana Tsunami, Idul Fitri pada Januari 2002, dan peristiwa tak diketahui pada Desember 2005 dan juga September 2008. Peristiwa-peristiwa tersebut berdampak positif terhadap CPI. Sebaliknya, peristiwa tak diketahui pada April 2002 dan Juli 2003 memberikan dampak negatif pada CPI. Model ini memiliki RMSE (kesalahan standar) sebesar 0,184 dan nilai kurtosis yang tinggi yang mengindikasikan bahwa residual memiliki pola leptokurtik. 


\section{DAFTAR PUSTAKA}

Anonym, (2007), Ten Years after Monetary Crisis (Preparation to Face Second Crisis), Info Bank Publishing, Jakarta.

Bhatacharyya, M.N., and Layton, A.P. "Effectiveness of Seat Belt Legislation on the Queensland

Road Toll - An Australian case study in intervention analysis", Journal of American Statistics Association, 1979, 74, p. 596-603.

Brockwell, P.J., and Davis, R.A., (1996), Introduction to Time Series and Forecasting, SpingerVerlag, New York.

Bowerman, B.L. and O'Connell, R.T., (1993), Forecasting and Time Series: An Applied Approach, $3^{\text {rd }}$ edition, Duxbury Press, California.

Dholakia, Kruti. "What Has Affected The Unemployment Rates in The USA: Preliminary Analysis

of The Last 12 Years-Elections and 9/11", Midwestern Business and Economic Review, 2003, 32, p. 34-43.

Hamilton, J.D., (1994), Time Series Analysis, Princeton University Press, New Jersey.

Kendall, S.M. and Ord, J.K., (1990), Time Series, $3^{\text {rd }}$ edition, Edward Arnold, London.

Leonard, M., (2001), "Promotional Analysis and Forecasting for Demand Planning: A Practical

Time Series Approach", SAS institute Inc, USA.

Parwitasari, D., "Modeling Transportation CPI in Surabaya which Contains of Structural Change", Unpublished Bachelor Final Project, Department of Statistics, Institut Teknologi Sepuluh Nopember. 2006,

Rupingi, A. Slamet, "Intervention Analysis and Generalized Autoregressive Conditional Heteroskedasticity (GARCH): Indonesia CPI Case Study", Unpublished Bachelor Final Project, nDepartment of Statistics, Institut Teknologi Sepuluh Nopember, 2001.

Rosa, B. Citra, "The effect of Fuel Price in Each Commodity and Services of Indonesia CPI 19982005", http://youngstatistician.com/?pilih=skripsi\&nip=se10604, (2006).

Suhartono, "Theory and Application of Pulse Function Intervention", Jurnal MatStat, 2007, 7(2), p. 191-214.

Tsay, R.S, (2002), Analysis of Financial Time Series, John Wiley \& Sons, Inc., New Jersey.

Valadkhani, A. and Layton, A.P., "Quantifying the Effect of the GST on Inflation in Australia's Capital Cities: An Intervention Analysis", Australian Economic Review, 2004, 37(2), p. 125138.

Wei, W.W.S, (1990), Time Series Univariate and Multivariate Methods, Addison Wesley Publishing Company Inc., Canada. 